\title{
Antepartum uterine rupture in a woman with previous iatrogenic uterine perforation
}

\author{
Alina Seixas 다, ${ }^{1}$ João Abreu-Silva 다 , ${ }^{2}$ Claudina Carvalho, ${ }^{1}$ Graça Ramalho ${ }^{1}$
}

${ }^{1}$ Gynaecology/Obstetrics, Centro Hospitalar de Vila Nova de Gaia/ Espinho, EPE, Vila Nova de Gaia, Portugal

${ }^{2}$ Gynecology/Obstetrics, Centro Hospitalar Tâmega e Sousa, EPE, Penafiel, Portugal

\section{Correspondence to}

Dr Alina Seixas;

alina.seixas@gmail.com

Accepted 15 July 2020

\section{DESCRIPTION}

A 32-year-old pregnant woman, gravida 2, para 0 , presented at 34 weeks of gestation with lower right quadrant abdominal pain, radiating to the lumbar region.

She had a history of pre-viable premature rupture of membranes at 22 weeks of gestation due to cervical insufficiency 2.5 years before. Considering the poor prognosis, she had requested a termination of pregnancy, which was complicated with retention of placental fragments. She was then subjected to uterine curettage, during which uterine perforation was suspected. The situation was managed expectantly, without further complications. During the current pregnancy, a McDonald cerclage was placed at 14 weeks of gestation.

At admission, the patient was haemodynamically stable, with normal abdominal physical examination and inconclusive right costovertebral angle tenderness test. Gynaecological examination and ultrasonography (US) revealed no significant findings; cervical length was $16 \mathrm{~mm}$. Cardiotocography showed reassuring fetal status and a pattern of uterine irritability. Her clinical situation remained stable during the first 23 hours following admission, after which she showed a progressive clinical deterioration, culminating with the eventual onset of acute abdomen. Abdominopelvic US revealed free peritoneal fluid, and blood tests showed a fall in

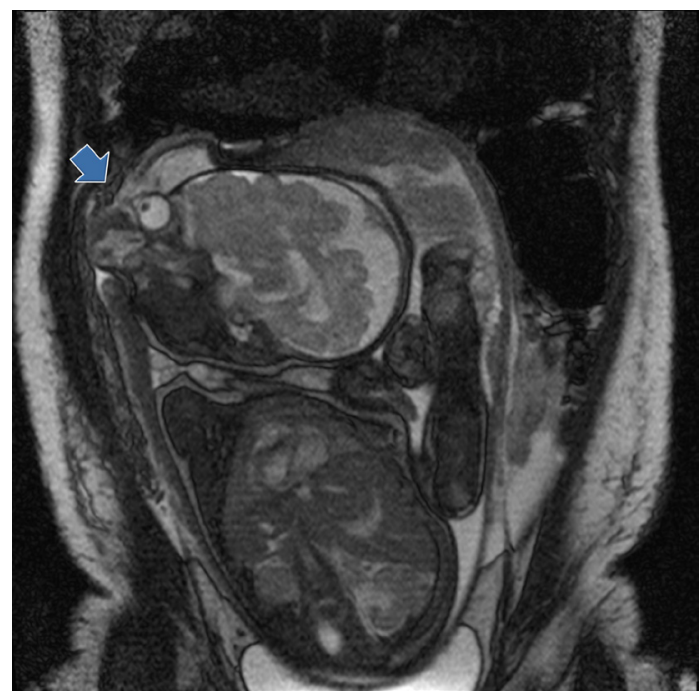

Figure 1 Coronal plane of the abdominopelvic MRI scan, showing a transmural defect on the uterine fundus (on the right side) and fetal parts protruding through the uterine wall (arrow).

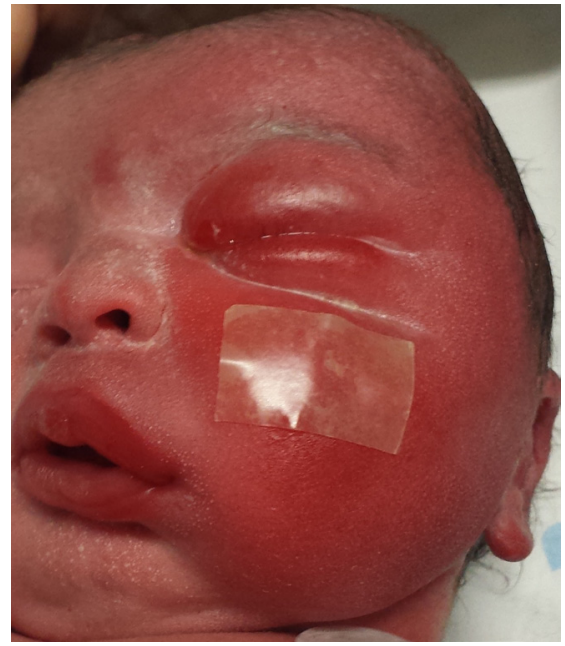

Figure 2 Newborn's facial deformity (edematous and erythematous left side of face), probably a consequence of protrusion through the uterine laceration which prevented more severe blood loss. (Photograph provided by the patient).

\section{Patient's perspective}

What can I say about the most memorable experience of my life? When I was admitted to the A\&E with abdominal pain, I never thought it could be something so serious. But in the morning after being hospitalised, I was sick and then felt an unbearable pain, the worst I'd ever felt. I wasn't able to stand. I realised there and then that something very serious was going on. I asked to speak with my obstetrician and I didn't let anyone examine me until she was present. I knew she would believe me about the pain I was feeling at that moment (after all, the medical team who had looked after me and witnessed everything had downplayed it, claiming that it was a gastroenteritis). I only calmed down after speaking with her. She explained to me that they were going to carry out some tests to understand what was happening. Long hours of uncertainty went by, but with the best outcome we could have hoped for. I owe it to the medical team that always accompanied me, believed in me and never gave up on us. If we are here today to tell the story, we owe it to them (especially to my obstetrician, to the operating team, as well as the neonatal unit). My sincere thanks to everyone. (Translated from Portuguese) 
haemoglobin level of $1 \mathrm{~g} / \mathrm{dL}$ and elevated inflammatory markers. Simultaneously, acute appendicitis had been deemed unlikely on observation by general surgeons and excluded by pelvic MRI.

The MRI led instead to the suspicion of a uterine rupture. Figure 1 shows the MRI scan result, which reveals a transmural defect on the uterine fundus, on the right side, and fetal parts protruding through the uterine wall.

An exploratory laparotomy was performed 32 hours after admission, confirming the uterine rupture by the presence of a moderate haemoperitoneum and a transmural fundal tear (6 $\mathrm{cm} \times 3 \mathrm{~cm}$ ), with protrusion of fetal parts. A lower segment caesarean section was performed and the fetus extracted in pelvic presentation. The fundal tear was successfully repaired. The patient received 2 units of packed red blood cells after surgery and was discharged on the fourth postoperative day without any complications.

The newborn presented an Apgar score of 7 at 1' and 9 at 5' and weighed $2720 \mathrm{~g}$. He had a facial deformity, as shown in figure 2. This was probably a consequence of protrusion through

\section{Learning points}

- Although a prior caesarean section is considered the main risk factor for uterine rupture in resource-rich countries, ${ }^{1}$ women with any uterine scar, including from uterine perforation, should also be considered at risk. ${ }^{23}$

- Medical staff should keep a high level of suspicion for uterine rupture in such pregnant women presenting with acute abdomen, even before labour. ${ }^{4}$ the uterine laceration, which is what likely contained the haemorrhage, enabling a positive outcome for both mother and child. The baby recovered well and the facial deformity disappeared. He stayed in the neonatal unit for 8 days due to prematurity, with a favourable course and no associated complications. His psychomotor development has been normal to date (5 years).

Contributors AS wrote the case report and assisted in antenatal appointments and inpatient care; JAS made the diagnosis, was the main surgeon and reviewed the manuscript; GR was responsible for the emergency care, was the assistant surgeon and reviewed the manuscript; CC followed the patient in antenatal and postnatal appointments, contributed for diagnosis and management of care and reviewed the manuscript.

Funding The authors have not declared a specific grant for this research from any funding agency in the public, commercial or not-for-profit sectors.

Competing interests None declared.

Patient consent for publication Obtained.

Provenance and peer review Not commissioned; externally peer reviewed.

\section{ORCID iDs}

Alina Seixas http://orcid.org/0000-0002-7064-910X

João Abreu-Silva http://orcid.org/0000-0002-9165-0302

\section{REFERENCES}

1 Landon MB, Heather F. Uterine rupture: After previous cesarean delivery. In: Post TW, ed. UpToDate. Waltham, MA, 2020. https://www.uptodate.com/contents/uterinerupture-after-previous-cesarean-delivery

2 Ghahramani L, Moslemi S, Tahamtan M, et al. Antepartum uterine rupture occurring at the site of a Peviously repaired dilatation and Curettage-Induced perforation: a case report. Bull Emerg Trauma 2013;1:96-8.

3 Nkwabong E, Kouam L, Takang W. Spontaneous uterine rupture during pregnancy: case report and review of literature. Afr J Reprod Health 2007;11:107-12.

4 Dow M, Wax JR, Pinette MG, et al. Third-trimester uterine rupture without previous cesarean: a case series and review of the literature. Am J Perinatol 2009;26:739-44.

Copyright 2020 BMJ Publishing Group. All rights reserved. For permission to reuse any of this content visit

https://www.bmj.com/company/products-services/rights-and-licensing/permissions/

BMJ Case Report Fellows may re-use this article for personal use and teaching without any further permission.

Become a Fellow of BMJ Case Reports today and you can:

- Submit as many cases as you like

- Enjoy fast sympathetic peer review and rapid publication of accepted articles

- Access all the published articles

- Re-use any of the published material for personal use and teaching without further permission

Customer Service

If you have any further queries about your subscription, please contact our customer services team on +44 (0) 2071111105 or via email at support@bmj.com.

Visit casereports.bmj.com for more articles like this and to become a Fellow 